\title{
Nurse leader empowerment, challenges and coping strategies among nursing leaders in Pakistan: A qualitative descriptive study
}

\author{
Saleema Gulzar, Zia Sultana, Alishah Aziz \\ The Aga Khan University, Pakistan
}

Received: April 29, 2019

Accepted: July 2, 2019

Online Published: August 23, 2018

DOI: $10.5430 /$ jha.v8n5p18

URL: https://doi.org/10.5430/jha.v8n5p18

\begin{abstract}
Objective: Nursing is considered a growing profession worldwide, but nurses in developing world like Pakistan face challenges for their empowerment within and inter professions. The overwhelming feeling of being oppressed shatters nurses' confidence and self-esteem and hinders their growth and development of the profession as well.

Methods: To guide professional growth and empowerment of nursing in Pakistan, a qualitative descriptive study was aimed to discover challenges, strategies and outcomes of empowerment of nurse leaders in Pakistan. Twelve nurses serving as leaders in nursing organization of Pakistan, who fulfilled inclusive criteria were interviewed about their perception of the challenges, strategies and outcomes of empowerment for Pakistani nurses.

Results and Conclusions: Nurses in Pakistan are facing great turbulence regarding their professional empowerment, but nursing leaders are striving hard at personal, institutional and government levels to help nurse understand the dynamics of challenges of empowerment and adopt appropriate strategies to attain and retain empowerment.
\end{abstract}

Key Words: Nurse, Leadership, Power, Empowerment, Coping, Challenges and strategies

\section{INTRODUCTION}

Nursing is considered a growing profession worldwide ${ }^{[1]}$ and despite of it facing deteriorated image and social disapproval in LMICs like, Pakistan. ${ }^{[2-6]}$ The underlying reasons for not getting due recognition of nursing profession included lack of professional development and salary package, meager remunerations. It is evident that regardless of long duty hours and extreme efforts, no post service benefits offered to private nurses within the country. ${ }^{[7]}$

In addition to this there are power over structure exercised by the physicians to nurses in the healthcare system of Pakistan. ${ }^{[8]}$ Further to this, physicians are appointed in place of nursing leaders and nursing leaders are facing least acknowledgement, appropriate level of leaderships, justified promotions and higher grades to attain empowerment and professional respect and recognition. Though most of the time in Pakistan, nurses and nursing leaders are serving in low capacities and become oppressed ${ }^{[9]}$ through prejudiced and disempowerment by lack of professional growth opportunities and decision making. The overwhelming feeling of oppression shattered nurses' self-esteem ${ }^{[9]}$ and constrained their professional growth and development. Recent studies have demonstrated that in an empowerment practice environment nurse leaders can be empowered and challenged power structures surrounded in existing healthcare system and ac-

*Correspondence: Saleema Gulzar; Email: saleema.gulzar@aku.edu; Address: The Aga Khan University, Pakistan. 
quire knowledge and skills to develop leadership qualities and prepare themselves to reach professional hierarchy in nursing profession. ${ }^{[10]}$

Studies illustrated that the effects of empowerment in transforming underprivileged people if they are to change their lives. ${ }^{[11]}$ It allows people to gain mastery over their affairs, become aware of their oppression and recognized their inner power and potentials. ${ }^{[10]}$

Though, empowerment is a complex phenomenon based on contextual ground and it may depend as much on the institutions and leadership involved. In the overall context, the outcome of empowerment creates positive impact on professions and systems by enabling empowered people to lead, influence and invest in society to bring any positive change. Empowerment in relation to health care services a range of outcomes can be measured on psychological, organizational, and institutional levels; and within economic, political and legal spheres. Due to work stress and coping abilities the prevalence rate of depression or depressive symptoms among nursing professionals are higher than $20 \%$, considered high when compared with the general population.

Thus, empowerment is as important for nurses and nurse leaders as any other professionals to be able to deal with oppression, negligence or feel deprived of their rights and disrespected by the society they live in. Once empowered, the nurses may eventually generate positive impact on profession in terms of meeting the organizational goals and commitments as they found themselves content with their job $^{[9,12-14]}$ which in turns increase nurses' retention and productivity.

Recognizing the need of empowerment in health sector WHO launched an initiative in January 1987, named "Health for all, Leadership Development". The core principle behind this initiative was to motivate people, based on community mobilization principle, for leading their own national health care systems and its developmental processes in order to achieve the goal of health for all. It is high time for current and future nursing leaders in Pakistan, to adopt ways to empower themselves and bring a desirable change in nursing practices and profession.

Considerable research to explore and enhance empowerment within nurses has been carried out internationally, however the empowerment of nurse leaders within Pakistan has not much talked about.

This study aims to explore power structure that impede empowerment of nurse and nurse leaders and defines ways to improve nursing leadership within the practice environment which lead nurses towards a certain degree of empowerment,

Published by Sciedu Press leadership and self-determination through various strategies.

\section{MethodS}

\subsection{Study design}

A qualitative descriptive study design was used through purposive sampling. A sample of twelve nursing leaders were interviewed using the criteria as:

(1) Working in administrative capacities in hospitals or nursing schools and colleges of Pakistan for not less than 10 years;

(2) Given informed consent to share the relevant experiences from their professional life and allow audio recording of interview.

The researchers and participants have strategic visionary attributes in various process involved in nursing profession that enabled them to critically analyze constrains of empowerment they were experiencing.

\subsection{Recruitment process}

A seed list developed of nurses holding leadership position in various institutions at national level. The data collection process began on June and ended on October. All interviewees received an invitation letter and an informed consent form before the interview began. Preferably those who signed informed consent were recruited in the study.

\subsection{Data collection}

The data was collected by visiting the potential nursing leaders in person at their vicinity. The semi-structured interview guideline used, and all interviews lasted approximately 4560 minutes, were recorded and were face-to-face. The interviews transcribed and translated from local language to English by researcher.

\subsection{Data analysis}

The data were analyzed manually in the month of November, first by primary author and then by other research team members. Themes were extracted from data using content analysis. ${ }^{[15]}$ The data analysis process and final revision completed in six months.

\subsection{Ethical consideration}

The study was approved by the Ethical Review Committee of the Aga Khan University.

\subsection{Trustworthiness}

To ensure credibility and reliability of the data the transcripts were read by the researcher multiple times. Once, data was transcribed and translated, the transcriptions were given back to the respective study participants to review and 
verify whether the researcher had captured their true perceptions. The themes were constructed through conformability by the research team.

\section{Results}

The demographic data of study participants showed in Table 1. Most of the participants were qualified (diploma nurses to $\mathrm{PhD}$ ) and experienced nurses working in leadership capacities for approximately 10 years.

The findings of this study described below in Table 2 .

\subsection{Model of empowerment vs. disempowerment}

Nurse leaders cognitively engaged through a model of empowerment vs. disempowerment (see Figure 1) to sustain their empowerment in practice setting. It is recognized that the model comprised into three elements:

\section{Supporting}

2. Impeding

\section{Recognizing}

In supporting elements nurse leaders received social recognition and acceptance being a female nurse that facilitate empowerment and concomitantly impeding elements such as lack of respect $\&$ less opportunity in professional growth, lack of participation in policy making and less involvement in strategic decisions illustrated parallel components that impede empowerment. The relationship of empowerment and impeding elements developed a distinguish element that caused a symmetrical relationships for initiating continues struggling, driving forces and challenging ability against impeding elements towards empowerment.

Table 1. Demographic data of the study participants

\begin{tabular}{ll}
\hline Characteristics & Number \\
\hline Gender & 12 \\
$\quad$ Female & \\
Year of experience & 6 \\
$10-20$ & 5 \\
$21-40$ & 1 \\
$41-60$ & \\
Area of leadership & 6 \\
$\quad$ Nursing Service & 6 \\
$\quad$ Nursing Education & \\
Professional Experience RN diploma, DTA & \\
$\quad$ Undergraduate & 1 \\
$\quad$ Graduate & 4 \\
Post graduate & 3 \\
PhD & 2 \\
\hline
\end{tabular}

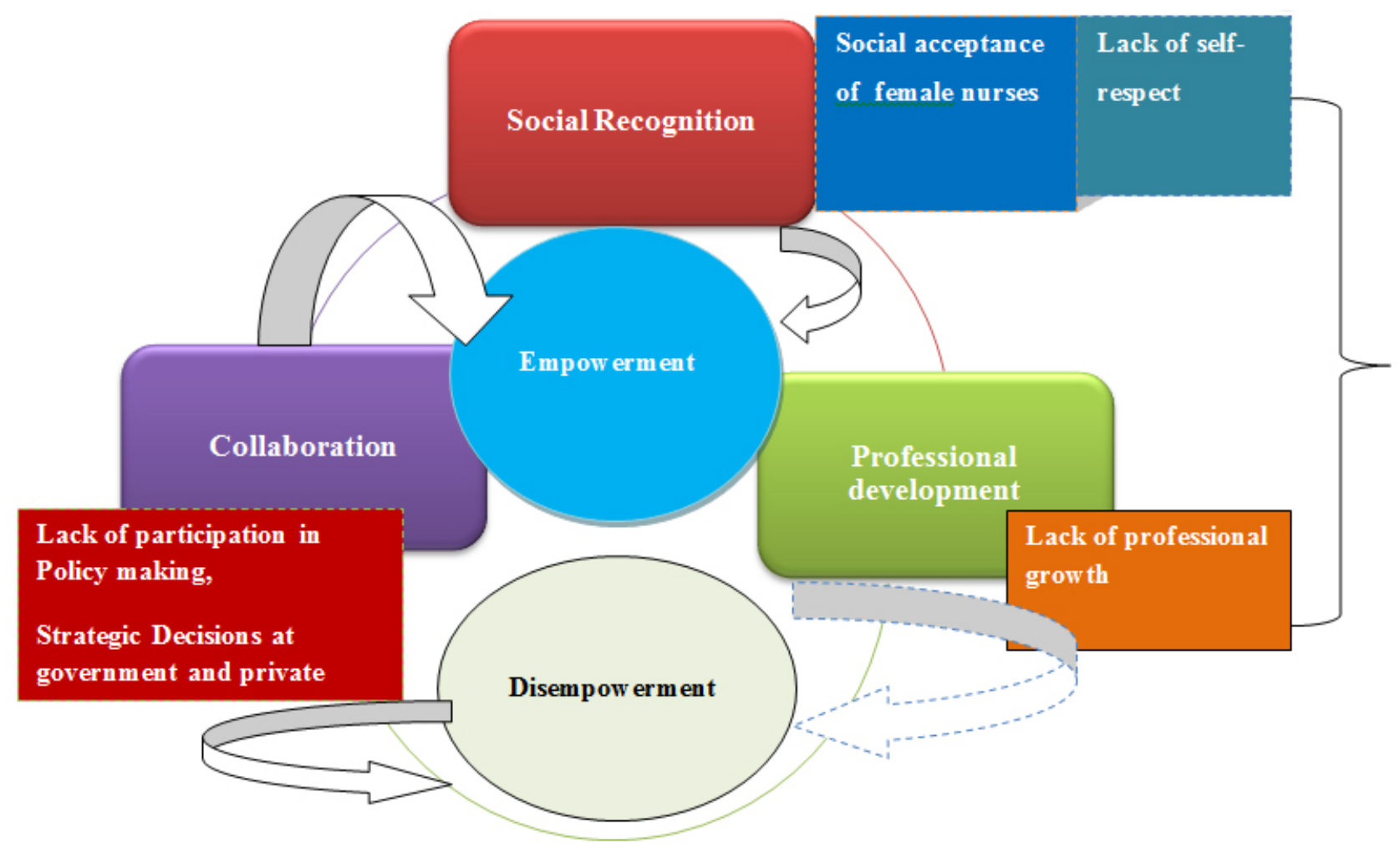

Figure 1. Model of empowerment 
Table 2. Qualitative findings: themes and quotations

\begin{tabular}{|c|c|c|}
\hline & Description & Insight \\
\hline \multicolumn{3}{|l|}{ Challenges } \\
\hline \multirow{2}{*}{$\begin{array}{l}\text { Shortage of } \\
\text { qualified } \\
\text { nursing leader }\end{array}$} & $\begin{array}{l}\text { The biggest challenge of lack of empowerment for nurses is } \\
\text { shortage of competent and strong nursing leaders who can voice } \\
\text { out, support and fight for nurses' rights. . }\end{array}$ & $\begin{array}{l}\text { "We lack well qualified nursing leaders who can fight for nurse' rights because nobody comes and gives you } \\
\text { the power in your hands. You have to fight for it, lobby for it; and negotiate for it. Competent nurse leaders are } \\
\text { highly required who can become the voice of nurses and advocate for their rights. (Code 008, line 42-47). }\end{array}$ \\
\hline & $\begin{array}{l}\text { Apart from incompetent leadership, scarce human, financial } \\
\text { and material resources is also counted as a challenge in gaining } \\
\text { empowerment that most of the participants reported. }\end{array}$ & $\begin{array}{l}\text { Our school of nursing commenced } 18 \text { years ago but, still it does not have its own building and hostel. We do not } \\
\text { have well qualified nursing teachers there are doctors who teach nurses at our college. (Code 009, line 16-19). }\end{array}$ \\
\hline $\begin{array}{l}\text { Lack of financial } \\
\text { resources }\end{array}$ & & $\begin{array}{l}\text { We only get limited budget, to develop nursing institution and once developed we are not provided with any } \\
\text { budget for smooth running of the institution ultimately the institution gets closed (Code 006, line 60-63). }\end{array}$ \\
\hline \multicolumn{3}{|c|}{ Adopted Strategies } \\
\hline Self-resilience & $\begin{array}{l}\text { Developing several personal traits like having an optimistic } \\
\text { problem solving approach, will power, effective coping with } \\
\text { stressors and utilizing critical thinking were seen an strong } \\
\text { strategy to help nurses to overcome the challenges of } \\
\text { empowerment. Nursing leaders in Pakistan, have adopted these } \\
\text { traits themselves and have experienced that with these trait they } \\
\text { can effectively combat challenging situations coming across } \\
\text { their professional life and the attempt of effectively dealing } \\
\text { with challenges in turn empowers them. }\end{array}$ & $\begin{array}{l}\text { We identify a problem, then we utilize a positive approach to that problem. If you explore the matter then you } \\
\text { understand it and then it's easy to decide. Like this, you identify proper people and the risk of picking up } \\
\text { wrong people is minimized (Code 001, line 197-199). }\end{array}$ \\
\hline Belief in God & $\begin{array}{l}\text { Study participants identified that as leaders they come across } \\
\text { many stressful situations where they use numerous coping } \\
\text { strategies to cope with them. Participants also believe that } \\
\text { having faith in God and self is the blessing, which assisted them } \\
\text { to cope with the challenges peacefully. The participant shared: }\end{array}$ & $\begin{array}{l}\text { Having empowerment and having decision making power causes considerable stress. We need to effectively } \\
\text { cope with stresses many a times I try obviously faith and peace and prayers work a lot in reliving stresses and } \\
\text { giving us power to fulfill this challenges. (Code 008, line 99-101) }\end{array}$ \\
\hline \multirow[t]{2}{*}{$\begin{array}{l}\text { collaboration } \\
\text { with government }\end{array}$} & $\begin{array}{l}\text { Building linkages, team work, networking, lobbying, and } \\
\text { collaboration with government and national regulatory bodies } \\
\text { are strategies which nurse leaders found to be very effective to } \\
\text { get empowerment in matters related to benefits of the nursing } \\
\text { profession or for developing service structures. }\end{array}$ & $\begin{array}{l}\text { There should be linkages between the government and the private sector. It is a two way process..... We have } \\
\text { given membership to private institutions and developed consistent rules for them, so that the private and } \\
\text { government nurses can share (participate) equally. Unless we do this, professional bodies cannot become } \\
\text { stronger (Code 006, line 329-335). }\end{array}$ \\
\hline & & $\begin{array}{l}\text { I talk to the government for matters that are not in my control, sometimes I get approval and the government } \\
\text { tries to help us. I think this is empowerment of nursing ... I write again and again to the government, give them } \\
\text { justification and fight a lot for my nurses. (Code 004, line } 71 \text { ). }\end{array}$ \\
\hline Higher education & It's a strongest strategy to become empowered & I think my higher education was an excellent strategy towards the road to empowerment. (Code 011 , line 78 ). \\
\hline $\begin{array}{l}\text { Adaptability } \\
\text { with gender } \\
\text { mainstreaming }\end{array}$ & $\begin{array}{l}\text { When new norms are introduced in system it is important for } \\
\text { nurses to understand the need and importance of that new norm } \\
\text { and try to adapt that and adjust accordingly. Inclusion of male } \\
\text { nurses was perceived as a threat for empowerment but } \\
\text { gradually accepted as an adaptive coping strategy }\end{array}$ & $\begin{array}{l}\text { Male nursing was introduced in Sind and we took is positively. The places, where our female could not go, } \\
\text { there we send our male nurses. Where our female nurses were afraid, there we forwarded our male nurses. } \\
\text { Males worked side by side with them (nurses) where female nurses were reluctant to speak, there the males } \\
\text { spoke. As a result, today the position of Sindh is different. (Code } 006 \text {, line } 80-83 \text { ). }\end{array}$ \\
\hline \multicolumn{3}{|c|}{ Outcome of Empowerment } \\
\hline $\begin{array}{l}\text { Improved self } \\
\text { confidence }\end{array}$ & $\begin{array}{l}\text { participants shared that enhanced leadership qualities, decision } \\
\text { making powers and a raise in nurses' image are the most } \\
\text { rewarding personal outcomes of empowerment }\end{array}$ & $\begin{array}{l}\text { There are a lot of benefits of getting empowered. When you are empowered you become authorized to perform } \\
\text { different duties, it is easier for you to approach people. People respect you and shoe willingness to work with } \\
\text { you I can easily influence and convince people because I am empowered. Overall, the benefit is that I can use } \\
\text { my powers to work to uplift nurses and nursing as a whole. (Code 011, line 85-83). }\end{array}$ \\
\hline Progressive & Empowerment excel motivation towards achieving objectives & $\begin{array}{l}\text { Empowerment makes you feel motivated, competent and feel confident. When there is an internal locus of } \\
\text { motivation, so internally you feel motivated. And because you are empowered, you achieve and because you } \\
\text { achieve people feel and therefore people appreciate what you do and you get more motivated, so in that way } \\
\text { empowerment helps in achieving motivation achievement and the locus of control consequently, your } \\
\text { confidence and competence and your self-esteem will obviously get better. (Code } 008 \text {, line 111-113). }\end{array}$ \\
\hline \multirow[t]{2}{*}{ Self-efficacy } & $\begin{array}{l}\text { Empowerment is reciprocal once get empowered as nurse } \\
\text { leader }\end{array}$ & $\begin{array}{l}\text {... when you get empower as a woman you feel that it is your family that also gets empowered, because being } \\
\text { female you instill that confident in your children. I feel that this empowerment goes a long way for nurses. } \\
\text { (Code } 008 \text {, line 118). }\end{array}$ \\
\hline & & $\begin{array}{l}\text { "To me nursing empowerment equals to women empowerment, equal half of this society's empowerment" } \\
\text { (Code 008, line 118). }\end{array}$ \\
\hline \multirow{4}{*}{$\begin{array}{l}\text { Social } \\
\text { acceptability and } \\
\text { recognition }\end{array}$} & & $\begin{array}{l}\text { Raise in nursing image, improvement in quality patient care, enhance participation of nurses in policy } \\
\text { development and resource development. }\end{array}$ \\
\hline & & $\begin{array}{l}\text { All the government medical and paramedical professionals respect us now. Now people have got the awareness } \\
\text { that nurses are empowered for taking actions. Due to this, the image of nursing has raised (Code 006, line } \\
36-38 \text { ). }\end{array}$ \\
\hline & & $\begin{array}{l}\text { I have seen that empowerment brings recognition. At our institution the senior management, our chancellor has } \\
\text { given us empowerment and for that nurses are recognized here. People respect us, doctors, the support staff } \\
\text { because they see the dignity and the equal empowerment to recognition and I think this is another benefit of } \\
\text { empowerment. (Code 008, line 120-121). }\end{array}$ \\
\hline & $\begin{array}{l}\text { Self-efficacy of nurse leader reflects the wider benefit of } \\
\text { patients in terms of decreasing costing of hospital stay }\end{array}$ & $\begin{array}{l}\text { Once patients will recover in shorter time period, you will be benefited at the national level. If a patient is } \\
\text { admitted in the hospital for longer duration i.e. for } 20 \text { days, it is counted as the patient's loss. If he recovers } \\
\text { within } 10 \text { days then his family is saved from suffering, the government expense for } 10 \text { days will be saved and a } \\
\text { national level benefit can be achieved. (Code } 009 \text {, line } 44-49 \text { ). }\end{array}$ \\
\hline $\begin{array}{l}\text { Strengthening } \\
\text { policy }\end{array}$ & & $\begin{array}{l}\text { I think empowerment of nurses in Pakistan will allow them to get autonomy, in order to progress, in order to be } \\
\text { recognized as the professionals, in order to make an impact on the Health Care System, in order to be involved } \\
\text { in policy making, policy implementation, and policy formulation. (Code 008, line 150-151). }\end{array}$ \\
\hline
\end{tabular}


Nurse leaders derived a symmetrical relationship between empowerment and disempowerment which is framed by the practices about nurse leadership concerned with the power dynamics within the organizational structure and contrasted with the prevailing phenomenon that caused disempower- ment among nurse leaders. The context of empowerment and disempowerment phenomena are built upon the high degree of personal and professional practices through the journey of nurse leader (see Figure 2).

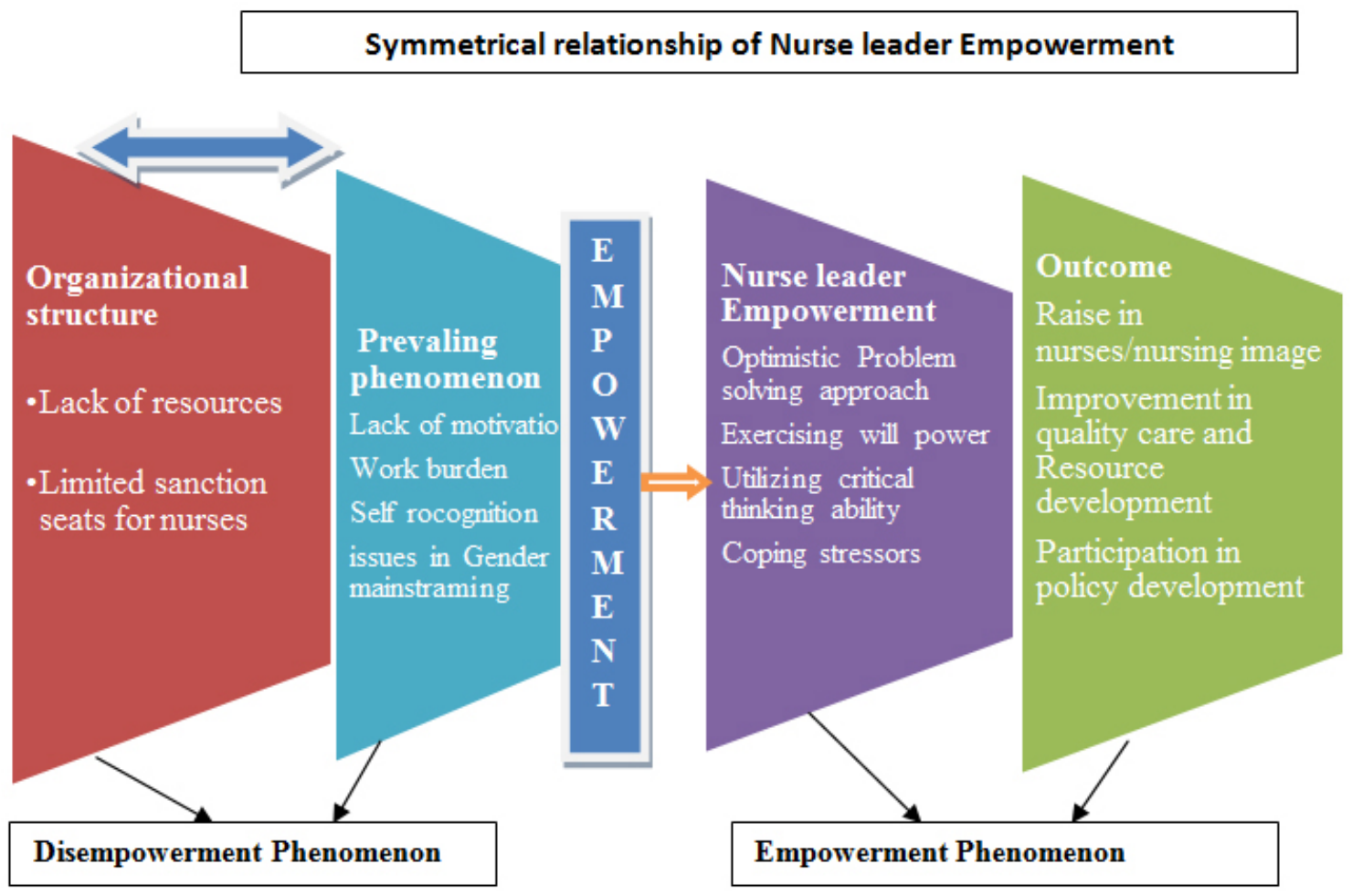

Figure 2. Symmetrical relationship between empowerment and disempowerment

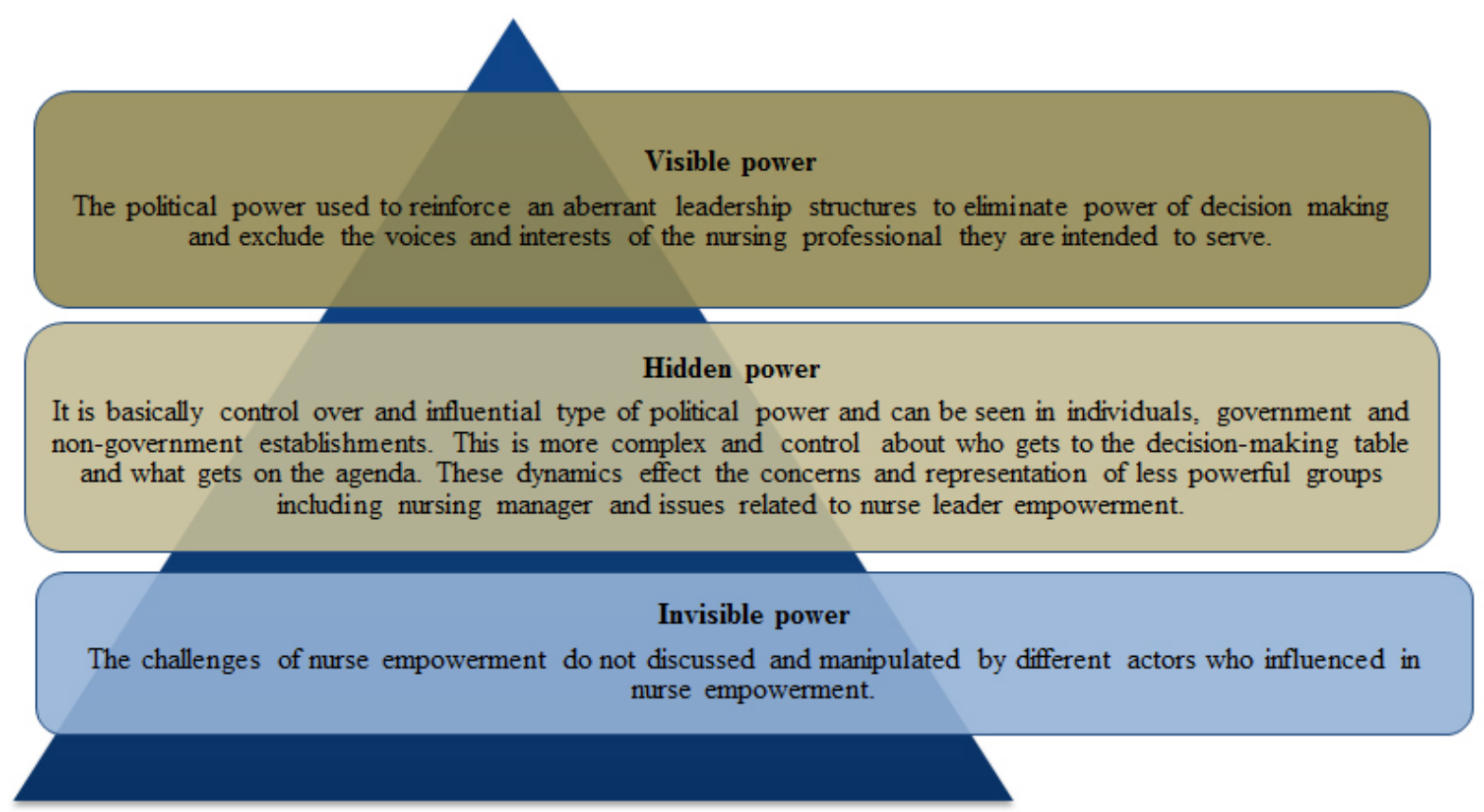

Figure 3. Power dynamics structure for empowering and disempowering nurse leaders 


\subsection{Political dynamics for Nurse Leader empowerment: findings.}

\section{favorable or constrain?}

The study revealed that Political dynamics play a two way role for nurse leader empowerment. It is a salient force and also directing a strategy to cope with challenges. To understand the extent of power dynamics at which nurse leader dealt with challenges to empower themselves the following power mechanism (see Figure 3 ) are derived from the
The power dynamics hence promoted a system of imbalance distribution of power to empower nurse leader empowerment. It is evident that nurse leaders were exercising coping mechanisms to tackle the power imbalance and find out an operational mechanism (see Figure 4) and enhance their skills to become more empowered.

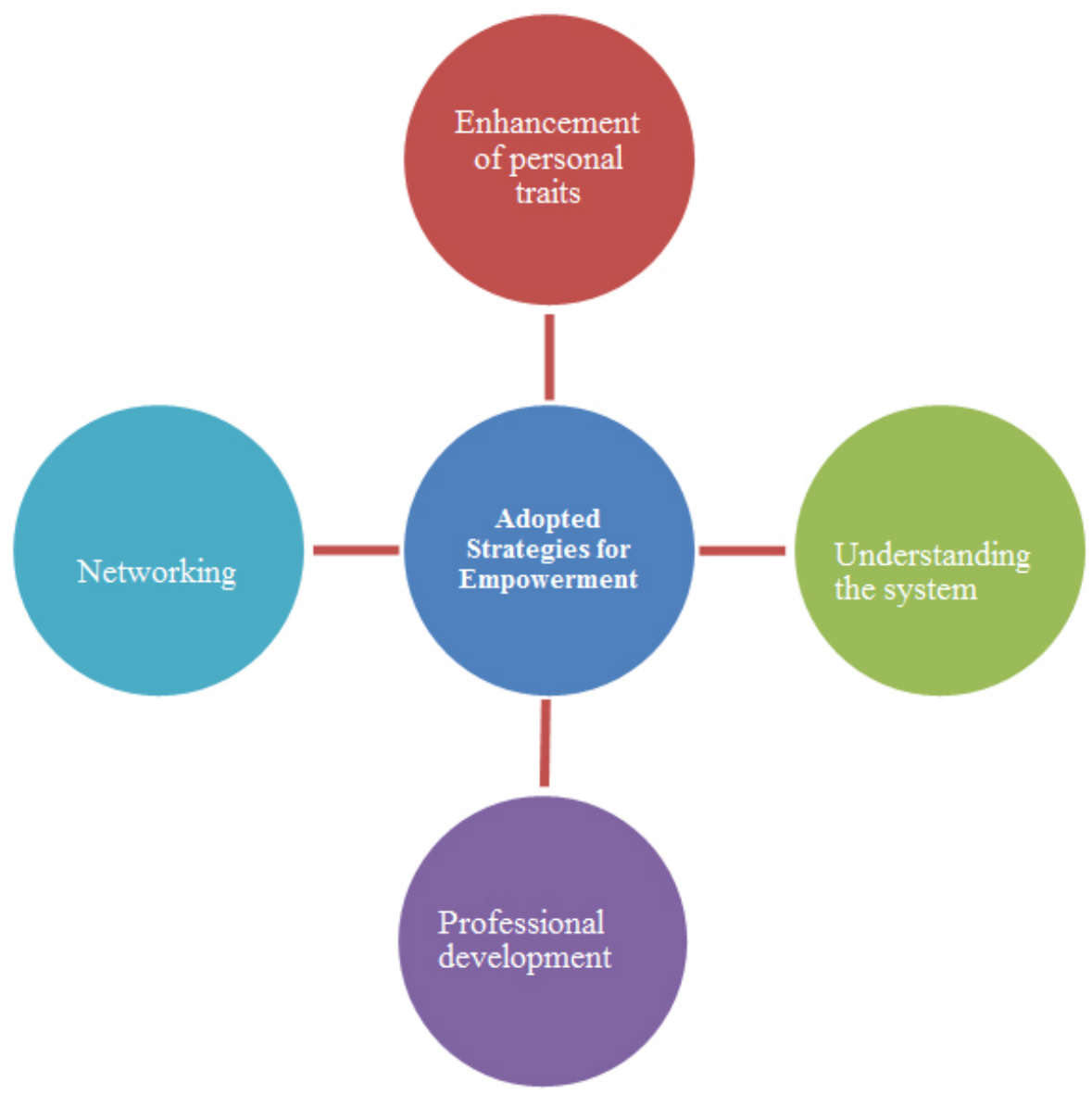

Figure 4. Operational mechanism to cope challenges for the empowerment of nurse leaders

Nurse leaders adapted several personal traits like having an optimistic problem solving approach, will power, effective coping with stressors and utilizing critical thinking to enhance their capabilities to become empowered.

\section{Discussion}

It is high time to reflect upon how much nurses are aware about the concept of empowerment particularly in relation to nursing profession in Pakistan? And to what extend power dynamics are related to empowerment? Power and politics are directly related to empowerment and are thought of as "the exercise of influence" to achieve control on local to national level politics. ${ }^{[16,17]}$ Mason DJ et al. ${ }^{[18]}$ in their
Feminist Model of Empowerment explain that nurses must understand the dynamics of power and politics and become the change agent for their organization in specific and their health care system as a whole. This has been true for nursing profession, since the time of Florence Nightingale, who used politics as an exercise to influence the then government to obtain substantial medical aid for wounded soldiers. ${ }^{[19]}$ Unfortunately, the political effectiveness for Pakistani nurses has been hampered by the negative societal image of nursing profession and women and politics. It has also been troubled by nurses own outdated perception of political behavior, as "unfeminine" and unprofessional. ${ }^{[18,20]}$ But nurse leaders in Pakistan shall take a bold step now to learn to 
modify their perceptions about power and politics. It is high time for Pakistani Nurse Leaders to effectively and conscientiously utilize the political skills and power they already possess to influence decision makers at national level and bring about positive changes for nursing profession within the country. ${ }^{[9,21]}$

Another challenge identified by study participants regarding nursing leadership in Pakistan, is that these leaders lack leadership qualities in terms of teamwork, delegation, decision making and raising their voices for nurses' rights. Study participants believed that as most of the nurse leaders in Pakistan are female, hence they tend to become submissive and get easily suppressed by others. Literature opposes the above idea and explains that women inherit leadership qualities more than men. Moreover, in comparison to men, women are observed to be more frequently demonstrating management attributes .e.g. effective decision making, collaboration, commitment and devotion, etc. ${ }^{[22,23]}$ But on the other hand there lies social, cultural and religious conditions which make female leaders to feel more suppressed. ${ }^{[24]}$ The same happens with nurse leaders in Pakistan, and they despite having effective leadership skills cannot exercise them because of the above mentioned conditions. To break away these conditions, women particularly nurses need to acquire their own autonomy and must exercise it when required. Literature highlights that when nurses exercise more autonomy in terms of decision making then it serves to be empowering and professionally satisfying contrary to low levels of professional autonomy, which eventually impede empowerment. ${ }^{[25]}$

The study findings depicted some strategies that nurse leaders in Pakistan have already acquired to attain empowerment, among which collaborative work with other health care providers and networking worked well for nurses. Laschinger HK and Smith LM $^{[26]}$ used the Inter-professional Collaboration Scale (IPCS) and was found that inter professional collaboration amongst health care team members is crucial to empowerment, and is highly regarded in their patient care setting. Moreover attributes such as effective communication, collegiality and getting peer feedback professionally have been identified as essential competencies ${ }^{[27-29]}$ which eventually helps them to find meaning in their work.

To conclude, though, nursing leadership is quite complex and challenging in Pakistan which at times influence negatively on nurse professionals' empowerment. Nonetheless with some adopted strategies, Pakistani Nurse Leaders are persistently moving towards the road of empowerment. This constant struggle, knowledge and addressing politics, quality education and effective use of transformational leadership attributes will be continually required by nurse leaders in Pakistan to ensure that nurses and nursing profession in Pakistan gets due recognition, respect and empowerment they deserve.

\section{CONFlicts OF INTEREST Disclosure}

The authors declare they have no conflicts of interest.

\section{REFERENCES}

[1] Somers MJ, Finch L, Birnbaum D. Marketing nursing as a profession: Integrated marketing strategies to address the nursing shortage. Health Marketing Quarterly. 2010 Aug 11; 27(3): 291-306. PMid: 20706896. https ://doi.org/10.1080/07359683.2010. 495306

[2] Fletcher K. Image: changing how women nurses think about themselves. Literature review. Journal of Advanced Nursing. 2007 May; 58(3): 207-15. PMid: 17474909. https ://doi.org/10.1111/j . 1365-2648.2007.04285.x

[3] Hemani H. History of Nursing in Pakistan: a struggle for professional recognition, M.ScN.thesis, University of Alberta, Alberta, Canada; 2003. 110-124 p.

[4] Schultheiss K. Imperial Nursing: cross-cultural challenges for women in the health professions: a historical perspective. Policy, Politics, \& Nursing Practice. 2010 May; 11(2): 151-7. PMid: 20679326. https://doi.org/10.1177/1527154410377356

[5] Takase M, Maude P, Manias E. Impact of the perceived public image of nursing on nurses' work behaviour. Journal of Advanced Nursing. 2006 Feb; 53(3): 333-43. PMid: 16441539. https: //doi.org/10.1111/j.1365-2648.2006.03729.x
[6] Hoeve YT, Jansen G, Roodbol P. The nursing profession: public image, self-concept and professional identity. A discussion paper. Journal of Advanced Nursing. 2014 Feb; 70(2): 295-309. PMid: 23711235. https://doi.org/10.1111/jan.12177

[7] Bahalkani HA, Kumar R, Lakho AR, et al. Job satisfaction in nurses working in tertiary level health care settings of Islamabad, Pakistan Journal of Ayub Medical College Abbottabad. 2011 Sep 1; 23(3): 130-3.

[8] Hayes LJ, O'Brien-Pallas L, Duffield C, et al. Nurse turnover: a literature review. International journal of nursing studies. $2006 \mathrm{Feb}$ 1; 43(2): 237-63. PMid: 15878771. https://doi.org/10.1016/ j.ijnurstu.2005.02.007

[9] Gulzar SA, Vertejee S, Khan K, et al. A qualitative study of nursing leader's perceptions of professional empowerment amongst Pakistani nurses. International Journal of Nursing Education. 2015; 7(3): 247 https://doi.org/10.5958/0974-9357.2015.00174.9

[10] Jennings L, Na M, Cherewick M, et al. Women's empowerment and male involvement in antenatal care: analyses of Demographic and Health Surveys (DHS) in selected African countries. BMC Pregnancy and Childbirth. 2014 Dec; 14(1): 297. PMid: 25174359. https ://doi.org/10.1186/1471-2393-14-297

[11] Pranis K. Restorative Justice, Social Justice, and the Empowerment 
of Marginalized Populations. Restorative Community Justice: Repairing Harm And Transforming Communities. 2001; 287.

[12] Manzoor QA. Impact of employees motivation on organizational effectiveness. Business Management and Strategy. 2012 Jan 1; 3(1): 1-2. https://doi.org/10.5296/bms.v3i1.904

[13] Pool S, Pool B. A management development model: Measuring organizational commitment and its impact on job satisfaction among executives in a learning organization. Journal of Management Development. 2007 Apr 17; 26(4): 353-69. https://doi.org/10.110 8/02621710710740101

[14] Schaurhofer M, Peschl MF. Autonomy: Starting point and goal of personal and social change: A constructivist perspective on knowledge management in empowerment processes. Kybernetes. 2005 Jan 1; 34(1/2): 261-77. https://doi.org/10.1108/036849205105 75834

[15] Graneheim UH, Lundman B. Qualitative content analysis in nursing research: concepts, procedures and measures to achieve trustworthiness. Nurse Education Today. 2004 Feb 1; 24(2): 105-12. PMid: 14769454. https://doi.org/10.1016/j.nedt.2003.10.001

[16] Des Jardin KE. Political involvement in nursing-education and empowerment. AORN Journal. 2001 Oct 1; 74(4): 467-75. https: //doi.org/10.1016/S0001-2092(06)61679-7

[17] Spenceley SM, Reutter L, Allen MN. The road less traveled: nursing advocacy at the policy level. Policy, Politics, \& Nursing Practice. 2006 Aug; 7(3): 180-94. PMid: 17071705. https ://doi.org/10 $.1177 / 1527154406293683$

[18] Mason DJ, Backer BA, Georges CA. Toward a feminist model for the political empowerment of nurses. Image: The Journal of Nursing Scholarship. 1991 Jun; 23(2): 72-7. PMid: 2060953. https://doi .org/10.1111/j.1547-5069.1991.tb00646.x

[19] Ellis JR, Hartley CL. Nursing in today's world: Challenges, issues, and trends. Lippincott; 1984.

[20] Henderson A. Emotional labor and nursing: an under-appreciated aspect of caring work. Nursing Inquiry. $2001 \mathrm{Apr} ; 8(2)$ : 130-8. PMid: 11882211. https://doi.org/10.1046/j.1440-1800.2001.0 $0097 . x$
[21] Zindani N. Pakistani nurses' vision for change. International Nursing Review. 1996; 43(3): 85-102.

[22] Post C. When is female leadership an advantage? Coordination requirements, team cohesion, and team interaction norms. Journal of Organizational Behavior. 2015 Nov; 36(8): 1153-75. https: //doi.org/10.1002/job. 2031

[23] Zenger J, Folkman J. Are women better leaders than men? Harvard Business Review. 2012 Mar 15; 15: 80-5.

[24] Kiamba JM. Women and Leadership Positions: Social and Cultural Barriers to Success. Wagadu: A Journal of Transnational Women's \& Gender Studies. 2008 Dec 1; 6.

[25] Papathanassoglou ED, Karanikola MN, Kalafati M, et al. Professional autonomy, collaboration with physicians, and moral distress among European intensive care nurses. American Journal of Critical Care. 2012 Mar 1; 21(2): e41-52. PMid: 22381995. https://doi.org/10.4037/ajcc2012205

[26] Laschinger HK, Smith LM. The influence of authentic leadership and empowerment on new-graduate nurses' perceptions of interprofessional collaboration. Journal of Nursing Administration. 2013 Jan 1; 43(1): 24-9. PMid: 23232176. https ://doi .org/10.1097/NNA . Ob013e3182786064

[27] Regan S, Laschinger HK, Wong CA. The influence of empowerment, authentic leadership, and professional practice environments on nurses' perceived interprofessional collaboration. Journal of Nursing Management. 2016 Jan; 24(1): E54-61. PMid: 25703584. https://doi.org/10.1111/jonm. 12288

[28] Bainbridge L, Nasmith L, Orchard C, et al. Competencies for interprofessional collaboration. Journal of Physical Therapy Education. 2010 Jan 1; 24(1): 6-11. https://doi .org/10.1097/00001416 $-201010000-00003$

[29] MacPhee M, Skelton-Green J, Bouthillette F, et al. An empowerment framework for nursing leadership development: supporting evidence. Journal of Advanced Nursing. 2012 Jan 1; 68(1): 159-69. PMid: 21722167. https://doi.org/10.1111/j.1365-2648.2011.0 5746.x 